\title{
Repatriation Plan for ISIS Members of Indonesian Citizenship from Iraq and Syria to The Homeland in The National Security Perspective
}

\author{
M. Alfi Rajabi Nasution \\ \{m.a.rajabin@gmail.com\} \\ Universitas Indonesia, Depok, Jawa Barat, Indonesia
}

\begin{abstract}
The defeat of ISIS against Syrian democratic forces in Baghouz Syria has left thousands of sympathizers displaced by territorial loss. They're detained and arrested to be relocated to a shelter. There are Indonesian citizens there, but the exact number of people who want to return to their homeland is unknown. Most of them are women and children who have radical ideologies. In this study, We want to describe the obstacles of the Government, which until now not yet to decided to repatriate Indonesian citizens to the homeland from the perspective of national security. This study uses descriptive qualitative research methods in explaining the phenomenon of displaced followers of ISIS after the defeat. The method used in collecting data is secondary data obtained through study literature The results of the study revealed that the Government of Indonesia needs to group them based on security guarantees, aka bringing home people with the lowest risk of threats and low vulnerability through eight steps, among others Identifying and screening identities document evidence; Conduct a legal assessment; Assesstment process of radicalism level; Checking the track record of trips; Collecting data on relations with radical groups and family or relatives in the territory of Indonesia; Conduct gender clustering; Taking back the oath of loyalty to the ideology of Pancasila, NKRI, and the 1945 Constitution; and Prepare well the roadmap for the method of deradicalization and disengagement.
\end{abstract}

Keyword: ISIS, Radical, Repatriation, Indonesian Citizen

\section{Introduction}

The world was shocked by the rise of the Khilafah announced by the spokesman of the Islamic Daula Sheikh Abu Muhammad al-'Adnani as-Syami hafizhahullah. The news was followed by the first official speech of Amirul Mukminin (Khilafah leader) Abu Bakr alHusayni al-Qurashi al-Baghdadi who declared the establishment of the Islamic State of Iraq and Syria (ISIS) on the first day of Ramadan 1435 H or 29 June 2014, at An-Nuri Mosque, Mosul City, Iraq. In his speech al-Baghdadi called for "immediate Hijra to the Islamic State because Syria is not only for Syrians and Iraqis not only for Iraqis, the Earth belongs to God, this Daula is a country for all Muslims, land for Muslims, all Muslims Islam. Anyone who is able to migrate to the Islamic State is obligatory" (Dabiq 01, 2014). After the incident, the propaganda about the Islamic State, which was Khilafah ala Minhajin nubuwwah or the life of the caliphate in following with the times of the Prophet Muhammad and his companions was spread massively and quickly to trigger the wave of migration of Muslims around the world. One-half year later, 
the UN Security Council declared that ISIS was an unprecedented global threat to international peace and security (Security Council, 2015). Prunckun defines threat as a determination to hurt others made by a threat agent, which consists of an individual entity, organization and state that has the intention arising from desires and expectations, and the ability arising from knowledge and resources to endanger and cause harm both in terms of physical, mental and emotional to the target of a threat object such as individuals, material and national security (Prunckun, 2010). This group has claimed to have religious, political and military authority for all Muslims in the world, as well as inviting it to join and support the existence of Islamic caliphate in the World (Organization of Islamic Cooperation, 2015). According to Alfi Rajabi (Nasution, 2019), ISIS propaganda can have a negative impact including motivation for qital jihad, allegiance/recruitment, increase motivation for amaliyah actions, decrease in the level of support for Pancasila ideology, contra to the democratic system, and reduce participation level in elections. This clearly illustrates the intention of ISIS to form an Islamic Caliphate with the ability to fight, has triggered Muslims from countries in all directions for an exodus or wave of migration (Hijrah) towards the land they dreamed of and dreamed of as their place justice and prosperity based on Islamic law enforcement, namely Iraq and Syria.

As a result, More than 42,000 foreign terrorists joined ISIS with more than 120 countries (between 2011 and 2016). More than 5,000 foreign terrorists have departed from Europe, including from Belgium, France, Germany, and the United Kingdom, significant numbers also came from Austria, Denmark, Filandia, Italy, Holland, Spain and Sweden (RAN, 2017). Whereas, official estimates of the number of ISIS members of Indonesian citizenship vary between relevant institutions and ministries, in 2017 the BNPT estimated that 1321 Indonesians were joining ISIS, Defense Minister Ryamizard Ryacudu estimated that 700 Indonesians joined ISIS in Syria and Iraq (Asmara, 2019). There have been 800 people, including Indonesian women and children, leaving for Iraq and Syria since the beginning of the conflict. In August, there were 568 Indonesians in Iraq and Syria, 69 people were killed in the conflict zone, and 183 people had returned/deported to Indonesia (Sales, Country Reports on Terrorism 2016, 2017). The Indonesian National Police Chief Gen. Sutarman said 56 Indonesian citizens were joining ISIS militants in Iraq and Syria, and 4 of them were reported killed among them by committing suicide bombings (Waluyo, 2014). Whatever the number, the departure was due to an ideological understanding, not by force, even they tried to depart by any means and mode through illegal channels. Such as selling property, falsifying identities/passports/other travel documents, pretending to want to study in the Middle East with the Cairo, Amman, and Mosul or Tirkit routes in Iraq, pretending to Umrah using the Jeddah-Jordan-Syria route, and pretending to travel to Turkey to go to Syria to join ISIS. ISIS ideology is very dangerous, because it justifies the killing of fellow Muslims who are do not agree with it and disbelieves the government of thogut. Thus, high potential becomes a threat if they return to their home country or other places later, because the brain has been washed to carry out jihad by violent means (qital jihad).

Various ISIS attacks outside its territories (Iraq, Syria, and Libya) in 2016 further confirm the existence of their acts and acts of terrorism. Most of these attacks have occurred in countries where there are groups that declare loyalty to support ISIS, such as Afghanistan, Egypt, Saudi Arabia, and Yemen. In other parts of the world where extremists and foreign terrorist fighters return to their countries of origin have also carried out terrorist attacks directed, assisted, and inspired by ISIS (Sales, Country Reports on Terrorism 2016, 2017). For example, the Brussels attack on 22 March 2016 was carried out by an operational cell (French-Belgian), which was the same as the Paris attack on 13 November 2015 (BBC News, 2016), this event also took place in Instanbul (Modak, 2016). The terrorist landscape is growing faster and more complex in 
2017, where ISIS has proven to be resilient, determined, easily adapted, and they can adapt to counterterrorism pressure from the United States and its international partners/coalitions. They can become more scattered and quietly turn to the internet to inspire and trigger attacks by their followers and sympathizers, and make them safer from conventional military surveillance. Furthermore, the return or relocation of ISIS members from the battlefield has contributed to producing terrorist network cadres that are connected to each other, experienced and modern who can plan and carry out terrorist attacks (Sales, Country Reports on Terrorism 2017, 2018). Even in Indonesia, ISIS sympathizers can use websites, social media, and personal messages to spread their radical ideology, raise funds, recruit and communicate with new followers. Besides, there are growing concerns when Indonesian ISIS members can return to their homeland from the battlefield (Syria and Iraq) by bringing military operational skills, experience, and training (Sales, Country Reports on Terrorism 2016, 2017). In a certain period, there will undoubtedly be a vulnerability of terrorist attacks against government officials (Police, TNI, and Intelligence) or other targets, spreading radical ideology, threatening the Pancasila ideology, and cannot fuse with the public.

In fact, the impact of the capabilities of ISIS members is quite shocking and unexpected from the United States and the coalition, marked by various acts and acts of terrorism through whatever means and methods that occur in the world have shown that the danger of ISIS has become an excess of global and national security vulnerabilities and cannot be underestimated, so members of ISIS who want to return to their homeland must be the main priority scale for the government of each country in the process of handling. According to researchers from the University of Copenhagen, (Heurlin \& Kristensen, 2010) there are six levels of measure of security actors namely first, individual security; second, community security, is security for social groups, communities, nations and organized national or ethnic entities; third, national security, is security for the state or nation; fourth, regional security is security for the region or region; fifth, international security is security for the international community which consists of most countries in the world; sixth, global security is security for the world. When compared with the impact caused by ISIS so far, security actors reach the fifth or even sixth level, because their actions and brutal actions not only cover national or regional national security issues, but have disturbed the security and peace of the international and global community.

Further developments after ISIS reached its heyday, according to data from The Carter Center, the collapse of ISIS territorial began to be seen when the Syrian demoratic forces (SDF) took over and control the City of Raqqah (ISIS Capital City de facto) in October 2017, even the American President The Donald Trump union declared that ISIS had been defeated and eliminated in Syria in December 2018 and February 2019. However, this assumption, contrary to the CIA's assessment, said that since August 2018, there were still 14,500 ISIS fighters living and hiding around Syria (The Carter Center, 2019). The ISIS group or its scattered soldiers even claim loyalty, so the ISIS threat will continue to affect security despite losing its territory. On March 22, 2019, US President Donald Trump again announced the defeat of ISIS against the Syrian democratic forces (SDF) marked by the fall of the last ISIS stronghold in Baghouz, Syria is a sign of the end of the Islamic State's caliphate (Riechmann \& Baldor, 2019). However, this is not the end of the Caliphate. According to Joseph V. Micallef, the defeat of ISIS in Syria did not end the violence there. It only forced it to turn into revolt. SDF officials estimate that there are still hundreds of ISIS militants hiding in the civilian population. ISIS will not admit defeat, abolish the Caliphate let alone the peace agreement (Micallef, 2019). In return and Expand article (Johnston, Mona, Clarke, \& Shatz, 2019), they have warned that the Islamic State is a formidable and adaptable organization, since 2000 founded by Abu Musab Al-Zarqawi they have survived to face various challenges for the survival of his life. This group has a well- 
organized bureaucracy, when a senior leader is killed or captured, then others will be ready to replace him. Despite facing difficult times, in early 2019, there were clear signs that the Islamic State had regrouped by building fake checkpoints in Iraq to set off destroying oil tankers and targeting Shiite civilians making pilgrimages. This illustrates that despite the loss of territory, the Islamic State continues its struggle, plans for guerrilla rebellion, maintains economic financial strength by extortion, business investment, fish farming, car sales, and cannabis cultivation with existing sleep cells (Schmitt, Rubin, \& Neff, 2019).

The nature and character of the fighting spirit of this group has been formed never to give up, even the loss of ISIS territory raises a new problem, following the defeat of ISIS in Baghouz, has made followers including women and children affiliated with ISIS abandoned. Subsequent developments, raising the issue that there is a global consensus that is pushing for a solution and urgent action needs to be taken in order to deal with thousands of ISIS followers, sympathizers, and affiliates, including women and children who are now captured and detained by Syrian democratic forces (SDF) in Syria Northeast for repatriation and prosecution (Hesen, McClure, \& Steinhardt, 2019). The SDF has also urged countries to take back their citizens on financial grounds and lack of resources imposed on the North and East Syrian Autonomous Administration (AANES). According to the reporter freelance Afshin Ismaeli (Sumandoyo, 2019), there were 38 Indonesian ISIS sympathizers who were detained in the Kurdish Camp and the Indonesian Government was considering repatriating them. There were 50 people who were identified as Indonesian citizens in Hol Camp and they asked for facilities and repatriation by the Government of the Republic of Indonesia, in Hol Camp itself there are 9000 ISIS family members who are accommodated there, it is complicated and challenging for the government to verify and validate ISIS members of Indonesian citizenship. According to the Rojava Information Center (Hesen, McClure, \& Steinhardt, 2019) it is known that the Indonesian Government repatriated Indonesian citizens from Northeast Syria between January and July 2019 with 27 family members, who were reportedly jailed by ISIS because one family member refused to fight for ISIS then escaped and surrendered to SDF.

A little description of the condition of Indonesian citizens who are in the shelter based on the latest report (IPAC Report No. 59, 2019), first, Al-Hol Camp is the largest camp, in mid2019 it accommodates 73,000 people with 94 percent are women (left by their husbands as a result of war) and incarcerated) and children, they live overcrowded in camps, without food, water, sanitation, and health services. An Indonesian woman named Sudarmini, who was six months pregnant, was found dead as a result of being beaten there. In June 2019, there were 200 Indonesian citizens in Camp Hol, and it is uncertain how many want to return to Indonesia; second, Al-Roj Camp on the border of Syria and Iraq. In May 2019, 1,700 people were accommodated there, as of November 2018, based on data from humanitarian organizations, there were 33 Indonesian citizens, mostly women, and children, including 15 children born in the Middle East. There was Utsman Mustofa Mahdamy, an IT expert from Solo, who said he regretted joining ISIS and hoped to return to Indonesia and was willing to work with the Government to dismantle the ISIS network (Briantika, Polisi Sambut Eks Kombatan ISIS yang Tobat \& Mau Kerja Sama, Tapi.., 2019).

From the discussion above, the problem is that not all ISIS members who claim to be Indonesian citizens can be trusted, while the Indonesian Government has difficulty in obtaining valid information on how many Indonesian citizens are in Syria and Iraq, the reason being that when they leave Indonesia, they are not said he would go to Syria, or he would stay in Syria to join ISIS. Some Indonesians who joined ISIS destroyed their travel documents and identities. Still, when the situation in Syria and Iraq became more difficult, they changed their mind and wanted to return to Indonesia. The dilemma is faced by the Government of Indonesia, such as 
two sides of a coin, it is not good if these people are left without citizenship, starving, tortured and displaced on humanitarian grounds, but on the other side there is the phenomenon of betrayal by a citizen of his country, The ideology of Pancasila and the 1945 constitution, in addition to that the citizens have been brainwashed, their thinking and mindset become radical like ISIS.

Therefore, the author will discuss this phenomenon to be able to give a view and a short description of the conditions or conditions academically that can be used as consideration for policymaking. In this study, the author will discuss and express opinions about the phenomenon of the status of Indonesian citizens traveling abroad based on the explanation of Government Regulation of the Republic of Indonesia Number 2 of 2007 concerning Procedures for Obtaining, Losing, Cancellation and Reclaiming the Citizenship of the Republic of Indonesia, Law of the Republic of Indonesia Number 6 of 2011 concerning Immigration which regulates matters of exit, entry, residence permit, passports and so on for citizens, and the Law of the Republic of Indonesia Number 5 of 2018 concerning terrorism. Based on the background of the problems and discussion outlined above, the question will be answered, namely, how is the national security perspective in dealing with the government's plan to repatriate ISIS citizens back to their homeland.

\section{Methods}

This study uses qualitative methods, according to Mc. Denzin, Lincoln, and Moleong stated that qualitative research is research that uses a scientific setting, intending to interpret phenomena that occur and is carried out in a way that involves a variety of other methods. This descriptive research, will describe, understand or explain a real phenomenon, for example, a condition or relationship that exists, opinions that develop, using scientific procedures to answer the problem actually based on data in the form of words, pictures, and not numbers (Moleong, 2005). Sources of data obtained in this study were obtained from various literature and research that had been done before. Using qualitative methods, it will explain how national political and security perspectives in responding and assessing threats / ATHG that will occur due to the scientific background that arises is the ongoing phenomenon related to the government's plan to repatriate Indonesian sympathizers who have joined ISIS in Iraq and Syria. The method used in searching data and information is literature research and analyzes secondary data obtained through literature review.

\section{Result and Discussion}

Considering that the acts of terrorism committed by ISIS members that have occurred so far constitute serious crimes that endanger state ideology, state security, state sovereignty, human values and various aspects of community life, nation, and state, as well as cross-border in nature, organized, and has an extensive network and has a specific purpose, the handling needs to be done specifically, planned, directed and continuous. According to Mahfud MD, the Chairperson of the National Suluh Movement (GSK) Movement (Nashrullah, 2019), Indonesian citizens in Syria who want to return to Indonesia have the right to return to their home countries. Even so, he replied that Indonesian citizens in Syria go to legal proceedings before they could return to Indonesia. Therefore, the process of returning or repatriating Indonesian citizens who 
have been poisoned by foreign ideologies needs to be given a legal basis to ensure the legal certainty of the ISIS members, to providing protection from threats that they will pose to the other 260 million Indonesians, the ideology of Pancasila and the national security. In terms of applicable law, this case can be reviewed based on the International Criminal Court, Government Regulation of the Republic of Indonesia Number 2 of 2007 concerning Procedures for Obtaining, Losing, Cancellation, and Reclaiming Indonesian Citizenship, Law of the Republic of Indonesia Number 6 of 2011 concerning Immigration and Law of the Republic of Indonesia Number 5 of 2018 concerning Terrorism.

\subsection{ISIS Crimes Viewed by International Criminal Court}

In the plan to return ISIS citizens back to the homeland, of course, it must be clear the track record of the organization that it once sheltered. This is important to know, because it is not known for individual whether Indonesian citizens who joined ISIS ever contributed, played a role or were directly or indirectly involved in organizational crimes that had been committed before. To minimize the evil that will be undertaken by ISIS members in the future, it needs to be studied and anticipated. According to Hesen in the writings of Bringing ISIS to Justice (Hesen, McClure, \& Steinhardt, 2019). Crimes committed by ISIS so far can be categorized into four types of categories that can be prosecuted in international justice mechanisms, including genocide crimes, crimes against humanity, war crimes, and aggression crimes. According to the opening of the Rome Statute, the main objective of the international criminal court (ICC) is to prevent the most severe crimes of concern to the international community, because these crimes cannot be left unchecked. The problem is whether the ICC has jurisdiction over an organization such as ISIS.

In the case of ISIS, it has been shown many times that it has the means to carry out widespread or systematic attacks, it still has control over various areas, its primary purpose is criminal activity against civilians and ISIS has repeatedly stated its intention to attack the population civilian. Based on this, it can be the basis that there is absolutely no doubt that the ICC can and must prosecute ISIS members for crimes against humanity. The following is an explanation of the crimes committed by ISIS based on the Rome Statute or ICC (Blick, 2018).

\subsubsection{Genocide}

Viewed from the Genocide Convention (UN Commission on Human Rights, 1948), Genocide is an action taken with the intent to destroy all or part of a national, ethnic, racial and religious group. These actions include, among others; first, the killing of group members; secondly, causing severe suffering to the souls and mentality of group members; third, intentionally creating living conditions that aim to carry out physical destruction in whole or in part; fourth, wearing measures intended to prevent births within the group; and fifth, forcibly transferring children from the group to another group. However, according to Lemkin in Steven L. Jacobs's article "Indicting Henry Kissinger: The Response of Raphael Lemkin" in (Jones, 2004), Genocide does not have to mean immediate annihilation of a nation. This is interpreted as an element of intention that has been planned through various actions aimed at destroying the main foundation of a nation's group life. The United Nations have recognized ISIS itself as a genocide against the Yazidis (UNHCHR, 2016). ISIS is also accused of genocide against Christians and Shia Muslims (Al-Rubaye, 2017).

\subsubsection{Crimes Against Humanity}


Viewed from the Rome Statute of the International Criminal Court article 7 on Crimes against Humanity (Rome Statute of the International Criminal Court, 2011) has the definition of a widespread or systematic attack directed against civilians by means of murder, extermination, slavery, forced displacement of the population, imprisonment, deprivation of physical freedom, torture, torture, rape, sexual slavery, all forms of sexual violence, apartheid crimes, enforced disappearances and other inhumane acts. Crimes against humanity need not be linked to armed conflict, but can occur in peacetime. The United Nations has found that ISIS is the cause of crimes against humanity because of atrocities and killings committed against Syrian civilians outside the scope of the battle. ISIS has occupied areas with diverse ethnic and religious communities and minorities, are forced to assimilate or flee (UNHCHR, 2014).

\subsubsection{War Crimes}

War crimes are actions committed by members of organized armed groups in the context of war, which constitute serious violations of international humanitarian law. The target can be civil or military (Hathaway, Strautch, Walton, \& Weinberg, 2019). For example, as Clarissa Ward reported, ISIS Members used new military equipment left behind by Iraqi soldiers who fled when ISIS captured a city in Northern Iraq. The UN found evidence of war crimes in the form of photographs of ISIS terrorist fighters who massacred Iraqi soldiers by executing massal of 1700 soldiers in one week (Ward, 2014) and killing 1000 civilians with slaughter in 17 days in Iraq (RTTNews Staff Writer, 2014). Besides, ISIS members also executed 250 Syrian troops when ISIS successfully seized an airbase in Raqqa Province (Westall \& Karouny, 2014). The war crimes and crimes against humanity that have been committed are sufficiently strong grounds to bring ISIS to the International Court of Justice.

\subsubsection{Crimes of Aggression}

Viewed from the Rome Statute of the International Criminal Court article 8 on Aggression Crimes (Rome Statute of the International Criminal Court, 2011) has a definition as planning, preparation, initiation or execution, by someone in an active position (political / military leader) to commit control over or to direct the political or military actions of a State, which plans, prepares, initiates or executes acts of severe aggression that constitute illegal use of force. However, because ISIS is a non-state actor, it is unlikely that ISIS, its leader Abu Bakr al Baghdadi, or other senior ISIS commanders will be tried on this basis.

\subsection{ISIS Indonesian Citizens Legal Status Viewed by Related Laws}

According to terrorism analyst Ridlwan Habib, currently, ISIS has a strategy that is conveyed by al-Baghdadi to his spokespersons who are spread through social media supporting ISIS, the plan to deal with the severe conditions they experienced today, the plan is Inhyas. Inhyas means returning to the desert, and can be defined to reunite with the community. Even though ISIS has no national territory, ideologically, the organizational system and followers who still declare their loyalty to the Khilafah still survive with their various social media platforms. When the Inhyas strategy is then followed by ISIS supporters who are citizens of Indonesia, it means they will enter villages in our area. They join into the community as if they have returned to society, but their ideology and mindset still think as ISIS fighters. This means that it is hazardous if they return to the middle of the community just like that, without being 
given maximum response. The Indonesian government through the BNPT and BIN has a deradicalization program to neutralize radical thought patterns and ideologies of terrorism prisoners. Still, Ali Wibisono, a researcher from the University of Indonesia, said that only 30 percent of the success rate of the de-radicalization program was carried out by the government against marriages, apart from the recidivism phenomenon (Wicaksono, 2019). Before bringing ISIS members back to Indonesian citizenship, it is necessary first to resolve the issue of legal citizenship status they face. Regarding this, the phenomenon of repatriation plans, the members of ISIS will later be faced with related laws.

\subsubsection{Government Regulation of the Republic of Indonesia Number 2 of 2007 concerning Procedures for Obtaining, Losing, Cancellation, and Reclaiming Indonesian Citizenship.}

In this regulation, there are alternative articles that explain that Indonesian citizens automatically lose their citizenship, among others because first, voluntarily taking an oath or declaring a loyal promise to a foreign country or part of that foreign country; secondly, voluntarily entering international service; third, enter the foreign army service without prior permission from the President; fourth, residing outside the territory of the Republic of Indonesia for 5 (five) years continuously not in the framework of state service, without valid reasons and deliberately not expressing his desire to remain an Indonesian citizen before the period of 5 (five) years ends, and every 5 (five) following years, the person concerned does not submit a statement of wanting to remain an Indonesian citizen to the Representative of the Republic of Indonesia whose jurisdiction covers the area of residence affected, even though the Representative of the Republic of Indonesia has notified the person in writing, as long as the person concerned does not become stateless.

Events that have occurred, the spread of the record of the activity of the declaration of the caliphate by al-Baghdadi in 2014 caused a reaction of support in the form of an oath of allegiance or affirmation of allegiance to ISIS which has led to the loss of citizenship for Indonesian citizens according to Government Regulation of the Republic of Indonesia Number 2 of 2007. The reaction of the engagement took place in several regions in Indonesia, including Medan, Cirebon, Sukoharjo, Karanganyar, Malang, Kediri, Lumajang, Poso, Bima, Makassar, and several other areas, are estimated to reach thousands. Here are some details that can be summarized by the author:

1. Wednesday, July 23, 2014, bai'at by Ust. Aman Abdurrahman with four terrorist inmates in Kembangkuning Prison.

2. Friday, July 25, 2014, bai'at by Ust. Abu Bakar Ba'asyir with 24 terrorist inmates in The Lapas Pasir Putih

3. Friday, July 18 2014, bai'at 100 people at Istiqomah Penatoi Bima Mosque, West Nusa Tenggara

4. Friday, July 25, 2014 bai'at by Santoso alias Abu Wardah as the Eastern Indonesian Muhajidin Command (MIT)

5. Info in Tawangmangu, Malang, the same activity is carried out, namely Bai'at.

6. Sunday, June 22, 2014, support by Jamaah Tauhid wal Jihad (TWJT) in Bekasi

7. Sunday, March 2, 2014, supported by 100 people of Tawheed Wal Jihad (TWJ) at Istiqomah Bima Mosque, West Nusa Tenggara

8. Monday, 7 July 2014, supported by DPW Indonesian Muslim League (LMI), North Sumatra 
9. Tuesday, July 15, 2014, support by the Daulah Islamic Support Forum (FPDI) at the new Baitul Makmur Solo Mosque, Sukoharjo

10. Sunday, August 3, 2014, support at Pekayon Jaya West Bekasi

Besides, not a few Indonesian citizens, both men and women who fought ISIS soldiers in Iraq and Syria as carried out by Bachrumsyah, Abu Jandal, Umar Jundul Haq, Abu Walid, Sudarmini and so on. There are survivors and still alive, many of them killed in battle for the fight to defend ISIS. Thus, since Indonesian citizens depart (migrate) to Syria and Iraq, it means that they live outside the territory of the Republic of Indonesia for 5 (five) years continuously, not within the framework of state service, without valid reasons and deliberately do not declare their desire to remain a citizen. The State of Indonesia, making allegations (oath of allegiance to ISIS), becomes an ISIS combatant and soldier or various other acts of crime outside the territory of the Republic of Indonesia should ISIS members of Indonesian citizenship not get recognition as citizens of the Republic of Indonesia Government again. Even if it is compared and seen from the data of the Ministry of Law and Human Rights regarding the number of convicted terrorist criminals who will be free in 2019 , there will be 25 people. Still, those who have pledged loyalty to Pancasila and the Republic of Indonesia are only two people, 23 others have not, even though the Government has handled all for an intervention and deradicalization program. This means that the intervention and deradicalization program from the Government for terrorism prisoners is still not effective and efficient, primarly to accommodate and handle all ISIS members of Indonesian citizenship if they are repatriated later. Therefore, it is necessary to have a very high accuracy for the Government to conduct screening to ensure and believe that Indonesian citizenship is still attached to ISIS members who will be repatriated to their homeland before being given further legal treatment.

\subsubsection{Law of the Republic of Indonesia Number 6 of 2011 concerning Immigration}

In Article 1, Immigration means the matter of the traffic of people entering or leaving the Territory of Indonesia and its supervision in order to maintain the upholding of the country's sovereignty. Every person who enters or exits Indonesian territory must pass through an immigration checkpoint consisting of a inspection at the seaport, airport, cross border post, or other place as the official entry point and exit point of the Indonesian Territory. According to article 8, every person who enters or exits the Territory of Indonesia is required to have a valid and valid Travel Document. The Republic of Indonesia's travel documents are the Republic of Indonesia Passport and the Republic of Indonesia Passport. Article 24 describes a passport consisting of diplomatic visas, official passports, and ordinary passports. Then in article 9, every person who enters or exits the Territory of Indonesia must pass an inspection carried out by an Immigration Officer at the Immigration Check Point.

Also, about how the process of entry or infiltration of the Indonesian citizens to Iraq and Syria, of course, their organization had planned to depart in illegal and very clandestine ways. Not by official means passing through the Immigration checkpoint then telling officers they would go to Iraq and Suriah. Of course, if such is the case, the Immigration Service will easily detect and coordinate with the National Police, BNPT, National Intelligence Agency, and Detachment 88 for prevention and arrest. If ISIS foreign terrorist fighters also have an official identity card and travel documents recorded by the authorities, it will be easy for the Ministry of Foreign Affairs to verify the Indonesian citizenship of ISIS members who are Indonesian citizens who are in shelters such as in Al Hol Camp or others. However, some burn passports and travel documents to avoid detection by the authorities, so they are not deported to their 
home countries. In fact, according to article 129, "every person who intentionally damages, changes, adds, subtracts, or removes, in part or in whole, the information contained in the Travel Document of the Republic of Indonesia or other Immigration Documents shall be liable to a maximum imprisonment of 5 (five)) year and a maximum fine of Rp. 500,000,000.00 (five hundred million rupiah) ". So, this makes everything complicated and complex. Meanwhile, the journey to ISIS is not as easy as is often assumed by many ISIS supporters, various modes and ways of how they depart for Iraq and Syria, there are various alternative methods to reach Iraq and Syria by avoiding detection from the authorities while on the trip.

For example, Like the story of Afif Abdul Majid and Agung in "The Road to ISIS: How Indonesian Jihadists Travel to Iraq and Syria" (Taufiqurrohman, 2015), on December 13, 2013, Afif and Agung left Indonesia for Syria by traveling to Kuala Lumpur from Solo and then to Istanbul by air. Then from Istanbul flew to Hatay, and was stationed at a local base controlled by ISIS in Homs Province in Al Husayniyah, then he met there with other ISIS Indonesian members. Later, he was transferred to another ISIS camp in Latakia, where he studied ISIS version of jihad and participated in military training such as shooting and handling weapons led by Abu Yusuf al-Maghribi, an ISIS instructor from Morocco. The Director of Bilateral Cooperation BNPT delivered another example, Brigadier General Budiono Sandi who said there were five modes of departure of Indonesian citizens who wanted to join ISIS in Iraq and Syria, including carrying out Umrah, visiting tours, visiting families, wishing to continue their education in the Middle East, and seeking new job (Felisiani, 2016). Regarding official travel documents for citizens who enter or enter the territory of Indonesia according to article 14 states that "in the event of doubt about the Travel Documents of an Indonesian citizen and/or his citizenship status, he must provide other evidence legal and convincing which shows that the person concerned is an Indonesian citizen ". If, ISIS members of Indonesian citizens are found doubtful about their travel documents because they are unable to provide valid and convincing evidence that shows that they are Indonesian citizens, then the person concerned will automatically be considered a foreigner.

\subsubsection{Law of the Republic of Indonesia Number 5 of 2018 concerning Terrorism}

This regulation was established with consideration of the involvement of persons or groups of people as well as the involvement of Indonesian citizens in domestic and/or foreign organizations that intend to engage in conspiracy that leads to criminal acts of terrorism, potentially threatening the security and welfare of the community, nation and state, and world peace. The definition of Terrorism in article 1 explains that "Acts that use violence or threat of violence that cause an atmosphere of terror or widespread fear, which can cause mass victims, and/or cause damage or destruction to strategic vital objects, the environment, living facilities public, or international facilities with ideological, political or security interference. " Then article 12 B explains that "anyone who deliberately organizes, provides, or participates in military training, paramilitary training, or other training, both domestically and abroad, with the intention of planning, preparing, or committing a Terrorism Act, and/or take part in fighting overseas for the Criminal Acts of Terrorism and shall be sentenced to a maximum imprisonment of 4 (four) years and a maximum of 15 (fifteen) years. Furthermore, article 13 A explains that "Anyone who has a relationship with the organization of Terrorism and intentionally spreads words, attitudes or behaviors, writings, or displays with the aim of inciting people or groups of people to commit Violence or Threats of Violence which can result in Criminal Acts of Terrorism sentenced to a maximum imprisonment of 5 (five) years. "Explanation of several articles in Law Number 5 of 2018 cited by the author is sufficient to illustrate that ISIS members 
of Indonesian citizenship shall be subject to legal sanctions if there is indeed an element of violation of criminal terrorism in his life. When compared with other countries, the British Government (BBC News, 2019) has expressly revoked the citizenship of Shamima Begum in the interests of national security. The Bangladeshi woman will also face the death penalty if she comes to Bangladesh.

Therefore, the Government is obliged to prevent terrorism, in that effort, the government takes steps to anticipate the principles of protecting human rights and the precautionary principle. Prevention is carried out through the first, national preparedness through community empowerment, enhancing the ability of the apparatus, protecting and enhancing infrastructure, developing terrorism studies, and mapping of radicalism-prone areas; secondly, counterradicalization activities carried out directly or indirectly through counter-narration, counterpropaganda or counter ideology in the form of oral, written, and other literacy media; and third, de-radicalization activities to eliminate or reduce and reverse the radical understanding of terrorism that has occurred. Deradicalization is carried out on suspects, defendants, convicts, and convicts given through stages of identification and assessment, rehabilitation, reeducation, and social reintegration. Meanwhile, for ex-convicts of terrorism, and people or groups of people who have been exposed to radical terrorism, deradicalization can be carried out through entrepreneurship and fostering national and religious insights.

With a series of events involving Indonesian citizens joining specific radical organizations that have been established as terrorist organizations or groups, or other organizations that intend to engage in conscientious objections that lead to criminal acts of terrorism, both inside and outside the country are appropriate characteristics with ISIS organizations. Because ISIS has caused public fear and impacted on political, economic, socio-cultural life, public order and security, national security, and international relations, certain radical organizations that lead to terrorist acts are transnational, organized, and have an extensive network of crimes, which have led to massive terrorism if not resolved immediately, will threaten peace and security, both nationally and internationally.

\subsection{Repatriation Viewed by The National Security Perspective}

Based on the 1945 Constitution of the Republic of Indonesia (Kartika, 2018), the state has four functions to realize the objectives of the state, namely the protection function, welfare function, educational function, and peacefulness function). This means that the state has the responsibility to protect, prosper, and educate its citizens and every person who is in the territory of their country, and to create world peace. State responsibility also applies to Pro-ISIS members of Indonesian citizens who are experiencing difficulties in Iraq and Syria. So that the four functions of the state become the philosophical basis of the aspired law (ius constituendum) to deal with the problem of terrorism to realize national security. The objective of realizing national security (Hikam, 2014) is to guarantee the dignity of humanity, the safety of citizens, and the territorial integrity of threats and disturbances of defense and security both from outside and within the country. Stable and controlled national security is a precondition for the smooth implementation of national development to realize national goals and interests (Ryacudu, 2015) Ryacudu also explained that global terrorism such as ISIS, other radical groups, and returning fighters are real threats that can disrupt and threaten national security.

Based on experience in the early 1980s, the Government had previously been cheated on the arrival of former Al-Qaeda combatants to Indonesia, namely the Mujahideen of Afghanistan, and the result was that they made a scene by committing suicide bombings in Bali in 2002 (Taher, 2019). Related to the repatriation plan of Indonesian citizens who are sympathizers of 
ISIS, the Government of the Republic of Indonesia has not yet determined its attitude. It has not yet formulated a plan to accommodate the wishes of the Indonesian citizens. The repatriation plan cannot be done partially. Stiill, it needs to be gathered and formulated in advance from various parties such as the Coordinating Ministry for Politics, Law and Security, BNPT, BIN, Polri, Densus 88, Ministry of Foreign Affairs, Ministry of Law and Human Rights through the Directorate General of Immigration, Ministry of Religion, Ministry of Social Affairs, Ministry of Manpower and so on. The matter of repatriation of Indonesian citizens is not just the transfer of people, but a matter of transferring problems and transferring radical ideology. So there must be assistance and monitoring of ISIS members who are Indonesian citizens who are currently in Syrian and Iraqi shelters. Critical opinion emerged from the Governor of the National Resilience Institute (Lemhannas) Agus Widjojo (Alfons, 2019) who revealed that the dissolution of ISIS in the Middle East posed a threat to unity in Indonesia, because former ISIS elements would return to their respective countries and bring radical ideologies from the outside. In addition, there are several groups in Indonesia that are intolerant of the ideology of Pancasila and want to replace the ideology of Pancasila, so it can be expected to be easily provoked and exposed to ISIS ideology, even they are feared to be vulnerable to cooperating in achieving the same goal, namely to make the NKRI a sharia, such as the symbiosis of mutualism.

The members of ISIS Indonesian Citizens currently in the Camp are mostly women, teenagers, and children. The aspect of psychological damage, even if only to women and children, is certain that the influence of the ideology of radical ISIS will still be at high risk and will develop extreme attitudes as a result of their social environment while in Syria. Therefore, the way they behave and their behavior will undoubtedly be at odds with the culture and social life of the Indonesian people in general. Keep in mind that the conditions of women who have joined ISIS while in Iraq and Syria are forced to marry into the wives of ISIS soldiers, funders, promoters, recruiters, suicide bombers, preparing children as jihadists, expanding networks, protecting organizations, building alliances and future jihadist printers. From some facts that have happened in Indonesia, ISIS women have the thickness of the ideology of radicalism that is stronger than their husbands. Besides, that a woman will be less likely to be suspected than a man.

In the IPAC report (IPAC Report No. 35, 2017), the ease of internet access through social media has made the desire of Indonesian women to be able to play a more active role in violent extremism more than men. Women's involvement in terrorism is not like Al-Qaeda / JI pro-ISIS women have their desires and wishes to be recognized as jihadists. Indonesian women are very instrumental in creating communication platforms through social media such as creating groups on Facebook and telegrams, forming fundraising charities, and providing various forms of logistical support for the pro-ISIS movement. In December 2016, the Indonesian police arrested at least four women for allegedly plotting to commit suicide bombings, facilitating ISIS fighters to go to Syria and Iraq, to help her husband, who also assembled explosives. Meanwhile, the condition of children and adolescents who live on the battlefield is never given any love education, only fed by doctrines and violent notions.

Therefore, Indonesia Goverment needs to use a soft and persuasive approach in conducting selection through extreme care and caution to bring Indonesian ISIS members back home to the country so as not to spread the virus to the public. Just as Nasir Abbas said, the government needs to be persuasive in making repatriation decisions and trying to uphold justice to ISIS citizens of Indonesia. This justice can be realized by not generalizing related to the negative stigma of ISIS terrorism for those who are in camps today, because not all of them have burned passports/identities, not all of them have acted as supporters (have contributed financial and material assistance to terrorist activities), not all of them have been involved in acts of extremist 
violence and terrorism. Even very sad if those who are deceived by ISIS propaganda to live prosperously and fairly under the auspices of the Islamic Khilafah are also said to be supporters, combatants and terrorists. Justice on this issue needs to be upheld on the basis of law and national security considerations.

Indonesian Government needs at least 1 year to process their return to the Homeland. Actions that can be taken include take a communication and diplomatic approach to the Syrian Government, the Iraqi Government, the Turkish Government and the SDF so that the entire handling process can be facilitated and carried out before entering the territory of the Republic of Indonesia to avoid intimidation from sympathizers and pro-ISIS groups in Indonesia and abroad or any party other than the Government of Indonesia. That is, some of the stages that will be carried out must be carried out in the place where the ISIS members of Indonesian citizenship are located, at least in a country that is close to the lodging camp. In the process of bringing them back to their homeland, there are eight (8) steps that need to be done by the government if they want to handle and give them a second chance to be able to help and remain loyal to the unitary state of the Republic of Indonesia, including:

1. Identifying and screening to ensure and verify through legal and convincing documentary evidence that shows that Indonesian citizenship is still attached to ISIS members who will be rescued and repatriated to the country. If they are unable to confirm valid and convincing evidence, the Government of Indonesia can decide to revoke Indonesian citizenship of the person concerned.

2. Conduct a legal assessment to find out whether there are elements of international criminal violations that have been committed while he joined ISIS.

3. Carry out a process of assessment to determine the level of viscosity of ISIS radicalism, into high, medium, and low levels, and determine the classification of their roles in ISIS such as whether they are only citizens who want to live under the Islamic caliphate, sympathizers and combatants. This is useful to give an estimate of the threat assessment and how much influence they will have if later resumed in Indonesian territory.

4. Checking the track record of trips that have been traversed, such as knowing where the path used for infiltration joined ISIS in Iraq and Syria, and which party facilitated his departure outside the territory of Indonesia.

5. Collecting data on relations with radical groups and family or relatives in the territory of Indonesia to anticipate planned communication to carry out acts of rebellion and betrayal.

6. Conduct gender clustering to determine the next handling process.

7. Taking back the oath of loyalty to the ideology of Pancasila, NKRI, and the 1945 Constitution, and will strip away all forms of identity that show that it is part of ISIS.

8. Prepare well the roadmap for the method of deradicalization and disengagement to be carried out. Such as preparing locations far from local residents, having adequate isolation space, adequate facilities, and entrepreneurship programs that support the success of deradicalization and disengagement program.

\section{Conclusion and Recommendation}


The request of Indonesian ISIS members to return to the country is a problematic and dilemma task that will be carried out by the government while upholding the principle of humanity. There are several obstacles to this, namely first, the Indonesian citizen ISIS will later face the law; second, those who went to Syria and joined ISIS did not have citizenship documents because they were burned or discarded, so it was difficult to prove and convince them that they were Indonesian citizens; and thirdly those who become ISIS volunteers, sympathizers, and combatants are likely to have very radical patterns of thought and ideology.

Indonesian citizens who went to Iraq and Syria were consumed by deception, empty promises and propaganda propagated by ISIS, all of which had caused casualties. It should be used as material for introspection for the Government of Indonesia, in dealing with transnational (cross-country) issues, information warfare, and propaganda between ISIS and the Government of Indonesia, which has harmed Indonesia. Counter information is needed to prevent this from happening again by the Government through the line of authority to the grassroots level by providing valid, fast, accurate and accurate education and information about a detailed explanation of the security situation that happened in Iraq and Syria, and the government's role in handling the issue. This is so that the public is not consumed by propaganda, which ultimately afflicts them.

The government, in principle, needs to group them based on security guarantees, aka bringing home people with the lowest risk of threats and low vulnerability. The government needs to communicate and diplomatic approaches to the Syrian democratic forces, the Syrian government, the Turkish government, and the Iraqi government to approve the planned program, provide repatriation and discretionary options (there are no obstacles to the policy process) for the Indonesian government to conduct assessments and identification of ISIS members Indonesian citizenship. The government needs to socialize all Indonesian people related to this repatriation policy plan and calculate the political consequences that will affect other strategic aspects, because if this policy can be implemented, there is still the possibility of the phenomenon of recidivism.

\begin{abstract}
Aknowledgement
I would first like to thank my parent and families, this paper could not be written without prayer, encouragement and sweet enthusiastic support of my parent and families. Thank You, Dr. Surya Wiranto, Dr. Margaretha Hanita, Dr. Hendrasmo and Dr. (C) Stanislaus Riyanta for always encouraging me to pursue my writing with confidence and diligently reading. Thankyou, especially for Albadr Nasution, M.Eng who was willing to proofread this research. I also thank to particularly my colleagues on XII and Brur for the respect that has been given so far, even the most difficult of times. Keep strive to always provide the best creation for the nation and country. I could not have achieved this capstone without all of your love and support along the way.
\end{abstract}

\title{
References
}


[1]. Alfons, M. (2019, August 7). Lemhannas Sebut Bubarnya ISIS di Timur Tengah Jadi Ancaman Nyata RI. Retrieved from detikNews: https://news.detik.com/berita/d-4655842/lemhannas-sebutbubarnya-isis-di-timur-tengah-jadi-ancaman-nyata-ri?tag_from=news_beritaTerkait

[2]. Al-Rubaye, A. (2017, August 18). U.S. Decries ISIS 'Genocide' of Christians, Other Groups. Retrieved from The Associated Press: https://www.nbcnews.com/news/us-news/u-s-decries-islamicstate-genocide-christians-other-groups-n792866

[3]. Asmara, T. (2019, March 29). Indonesia Verifying Citizenship of IS Families Stranded in Syria. Retrieved from benarnews.org: https://www.benarnews.org/english/news/indonesian/indonesiamilitants-03292019165508.html

[4]. BBC News. (2016, April 9). Brussels Explosions : What We Know About Airport and Metro Attacks. Retrieved from BBC News: https://www.bbc.com/news/world-europe-35869985

[5]. BBC News. (2019, May 3). Shamima Begum: IS bride 'would face death penalty in Bangladesh'. Retrieved from BBC News: https://www.bbc.com/news/world-asia-48154781

[6]. Blick, J. (2018, March 30). Can ISIS Be Prosecuted in the International Criminal Court for Crimes Against Humanity ? Retrieved from Florida International University Law Review: https://law.fiu.edu/can-isis-be-prosecuted-in-the-international-criminal-court-for-crimes-againsthumanity/

[7]. Briantika, A. (2019, May 17). Polisi Sambut Eks Kombatan ISIS yang Tobat \& Mau Kerja Sama, Tapi.. Retrieved from Tirto.id: https://tirto.id/polisi-sambut-eks-kombatan-isis-yang-tobat-mau-kerjasama-tapi-dK4P

[8]. Dabiq 01. (2014). The Return of Khilafah.

[9]. Felisiani, T. (2016, June 2). Lima Modus Pemberangkatan WNI Gabung ISIS ke Suriah. Retrieved from Tribunnews.com: https://www.tribunnews.com/metropolitan/2016/06/02/lima-moduspemberangkatan-wni-gabung-isis-ke-suriah

[10]. Hathaway, O., Strautch, P., Walton, B., \& Weinberg, Z. (2019, April 15). What is a War Crime? Retrieved from Just Security: https://www.justsecurity.org/63619/what-is-a-war-crime/

[11]. Hesen, F., McClure, T., \& Steinhardt, N. (2019). Bringing ISIS to justice Towards an international tribunal in North East Syria. Syria: Rojava Information Center.

[12]. Heurlin, B., \& Kristensen. (2010). International Security. Global Security and International Political Economy.

[13]. Hikam, M. A. (2014). In Menyongsong 2014-2019 (p. 347). Jakarta: CV Rumah Buku.

[14]. IPAC Report No. 35. (2017). Mothers to Bombers : The Evolution of Indonesian Women Extrimists. Institute for Policy Analysis of Conflict.

[15]. IPAC Report No. 59. (2019). Indonesia : Urgent Need For a Policy on Repatriation of Pro-ISIS Nationals From Syria. Institute For Policy Analysis of Conflict.

[16]. Johnston, P. B., M. A., Clarke, C. P., \& Shatz, H. J. (2019). Return and Expand? The Finances and Prospects of the Islamic State After the Caliphate. Santa Monica: RAND Corporation.

[17]. Jones, A. (2004). Genocide, War Crimes and the West: History and Complicity. Zed Books.

[18]. Kartika, S. D. (2018, May). Politik Hukum Pemberantasan Terorisme. Pusat Penelitian Badan Keahlian DPR RI.

[19]. Micallef, J. V. (2019, April 1). With ISIS Caliphate Defeated, Syrian Democratic Force Begin a New Chapter. Retrieved from Military.com: https://www.military.com/daily-news/2019/04/01/isiscaliphate-defeated-syrian-democratic-forces-begin-new-chapter.html

[20]. Modak, S. (2016, June 29). Brussels and Istanbul Attacks Expose Global Weaknesses in Airport, Subway Security. Retrieved from Conde Nast Traveler: https://www.cntraveler.com/stories/2016-0325/brussels-attacks-expose-global-weaknesses-in-airport-subway-security

[21]. Moleong, L. J. (2005). Metode Penelitian Kualitatif Edisi Revisi. Bandung: PT. Remaja Rosdakarya.

[22]. Nashrullah, N. ( 2019, Juni 20). Mahfud: WNI Eks ISIS Jalani Proses Hukum Bila Balik Kampung. $\quad$ Retrieved from Republika: https://nasional.republika.co.id/berita/nasional/hukum/ptdqzu320/mahfud-wni-eks-isis-jalani-proseshukum-bila-balik-kampung 
[23]. Nasution, A. R. (2019). From Al-Fatihin to Hanifiyah After The Ratification of Law No. 5/2018. Proceedings 3rd Indonesia International Defense Science Seminar (IIDSS) Volume 2 (p. 427). Jakarta: Indonesia Defense University.

[24]. Organization of Islamic Cooperation. (2015). Islamic Response to the Islamic State of Iraq and the Levant. MISH Model United Nations.

[25]. Prunckun, H. (2010). Handbook of Scientific Methods of Inquiry for Intelligence Analysis. Plymouth: Scarecrow Press.

[26]. RAN. (2017). Responses to returnees: Foreign terrorist fighters and their families. Brussels: Radicalisation Awareness Network (RAN) Manual.

[27]. Riechmann, D., \& Baldor, L. C. (2019, March 22). White House: ISIS Territory in Syria Eliminated. Retrieved from Military.com: https://www.military.com/daily-news/2019/03/22/whitehouse-isis-territory-syria-eliminated.html

[28]. Rome Statute of the International Criminal Court. (2011). The International Criminal Court.

[29]. RTTNews Staff Writer. (2014, June 24). UN : ISIL Militants Killed More Than 1000 Civilians In Recent Onslaught In Iraq. Retrieved from RTTNews: https://www.rttnews.com/2340932/isil-militantskilled-more-than-1000-civilians-in-recent-onslaught-in-iraq-un.aspx

[30]. Ryacudu, R. (2015). Buku Putih Pertahanan Indonesia. Jakarta: Kementerian Pertahanan.

[31]. Sales, N. (2017). Country Reports on Terrorism 2016. United States Department of State Publication Bureau of Counterterrorism.

[32]. Sales, N. (2018). Country Reports on Terrorism 2017. United States Department of State Publication Bureau of Counterterrorism.

[33]. Schmitt, E., Rubin, A. J., \& Neff, T. G. (2019, August 19). Eric Schmitt, Alissa J. Rubin and Thomas Gibbons-Neff. ISIS Is Regaining Strength in Iraq and Syria. Retrieved from The New York Times: https://www.nytimes.com/2019/08/19/us/politics/isis-iraq-syria.html

[34]. Security Council. (2015, November 20). Security Council 'Unequivocally' Condemns ISIL Terrorist Attacks, Unanimously Adopting Text that Determines Extremist Group Poses 'Unprecedented' Threat. Retrieved from United Nations: https://www.un.org/press/en/2015/sc12132.doc.htm

[35]. Sumandoyo, A. (2019, March 25). WNI Simpatisan ISIS di Suriah: 'Kami Minta Bantuan Bisa Pulang'. Retrieved from Tirto.id: https://tirto.id/wni-simpatisan-isis-di-suriah-kami-minta-bantuanbisa-pulang-dkb1

[36]. Taher, A. P. (2019, March 29). Apa Bahayanya Jika WNI Eks Simpatisan ISIS Balik ke Indonesia? Retrieved from Tirto.id: https://tirto.id/apa-bahayanya-jika-wni-eks-simpatisan-isis-balikke-indonesia-dkvh

[37]. Taufiqurrohman, M. (2015). The Road to ISIS : How Indonesian Jihadists Travel to Iraq and Syria. Counter Terrorist Trends and Analysis, RSIS NTU Singapore, 17-25.

[38]. The Carter Center. (2019). A Review of ISIS in Syria 2016 - 2019. Syria: The Carter Center Syria Project.

[39]. UN Commission on Human Rights. (1948). Convention on the Prevention and Punishment of the Crime of Genocide 1948 (E/CN.4/RES/1999/67), Article 2.

[40]. UNHCHR. (2014, November 14). UN Commission of Inquiry : Syrian Victims Reveal ISIS's Calculated Use of Brutality and Indoctrination. Retrieved from UN High Commissioner for Human Rights:

https://www.ohchr.org/EN/HRBodies/HRC/Pages/NewsDetail.aspx?NewsID=15295\&LangID=E

[41]. UNHCHR. (2016, June 16). UN Commission of Inquiry on Syria : ISIS is Committing Genocide Against The Yazidis. Retrieved from UN High Commissioner for Human Rights: https://www.ohchr.org/EN/HRBodies/HRC/Pages/NewsDetail.aspx?NewsID=20113\&LangID=E

[42]. Waluyo, A. (2014, August 14). Kapolri : 4 WNI Anggota ISIS Tewas di Suriah. Retrieved from VOA Indonesia: https://www.voaindonesia.com/a/kapolri-empat-wni-anggota-isis-tewas-disuriah/2413153.html

[43]. Ward, C. (2014, June 16). U.N. : ISIS Committing War Crimes in Iraq. Retrieved from CBS News: https://www.cbsnews.com/video/u-n-isis-committing-war-crimes-in-iraq/ 
[44]. Westall, S., \& Karouny, M. (2014, August 28). Video shows Islamic State executes scores of Syrian soldiers. Retrieved from Reuters.com: https://www.reuters.com/article/us-syria-crisis/videoshows-islamic-state-executes-scores-of-syrian-soldiers-idUSKBN0GS10O20140828

[45]. Wicaksono, A. (2019, July 10). Peneliti: Cuma 30 Persen Teroris Insaf karena Deradikalisasi. Retrieved from CNN Indonesia: https://www.cnnindonesia.com/nasional/20190710182004-20410985/peneliti-cuma-30-persen-teroris-insaf-karena-deradikalisasi 